\title{
Investigation of the Effects of Zinc Oxide Nanoparticles on Membrane Damage of Human Neuroblastoma Cell Lineage (SH-SY5Y) and Change of Tau Protein Structure by Spectroscopic Methods
}

\author{
Seyyedeh Elaheh Mousavi ${ }^{1, *(\mathbb{D})}$, Maryam Zivari Fard ${ }^{1 \mathbb{( D}}$, Seyed Mahdi Rezayat ${ }^{1(\mathbb{D}}$, Karim Naraki ${ }^{2 \mathbb{D}}$ \\ 1 Department of Pharmacology, School of Medicine, Tehran University of Medical Sciences, Tehran, Iran \\ 2 Department of Pharmacodynamics and Toxicology, School of Pharmacy, Mashhad University of Medical Science, \\ Mashhad, Iran \\ * Correspondence: semousavi@sina.tums.ac.ir (S.E.M.);
}

Scopus Author ID 55110393700

Received: 29.07.2021; Revised: 25.09.2021; Accepted: 29.09.2021; Published: 4.11.2021

\begin{abstract}
The use of nanoparticles in biological applications and cancer treatment has increased dramatically in the recent decade. Metal oxides of nanoparticles are among the most significant nanoparticles. Due to its suitable physical and chemical properties, zinc oxide is utilized in various fields, especially biomedicine and cancer treatment. This has raised a great deal of concern about the effects of nanoparticles on the body's biomolecules. The current study was set out to investigate zinc oxide nanoparticle's effects on neuroblastoma cells and their interaction with Tau protein. MTT and LDH tests were performed according to the instructions to evaluate the toxicity of zinc oxide nanoparticles on human neuroblastoma cells. Afterward, UV spectroscopy, CD spectroscopy, and fluorescence spectroscopy were performed according to the guidelines to investigate the interaction of zinc oxide nanoparticles with Tau protein. The results of the MTT assay showed a decrease in the survival rate of human neuroblastoma cells in a dose-dependent manner. The results of the Lactate dehydrogenase evaluation indicated an increase in LDH enzyme leakage from human neuroblastoma cells. Furthermore, zinc oxide nanoparticles form complexes with Tau-P through spontaneous and electrostatic interactions. The interaction of zinc oxide nanoparticles with Tau-P caused the accumulation of this protein and showed a significant change in the Tau-P structure. CD spectroscopy results showed that zinc oxide nanoparticles changed the $\alpha$-helix and $\beta$-sheet structure of the Tau protein. Besides, the results of the Stern-Volmer equation revealed that the type of interaction of zinc nanoparticles with Tau-P is static quenching interaction. In summary, these results demonstrated the safety aspect of zinc oxide nanoparticles in proteins and natural cells and their biological applications, which emphasizes further investigation on zinc oxide nanoparticles usage. Zinc oxide nanoparticles can manipulate the structure of Tau-P that can lead to Alzheimer's disease. Consequently, more studies on the use of zinc oxide nanoparticles are required.
\end{abstract}

Keywords: zinc oxide nanoparticles; lactate dehydrogenase; UV-visible; fluorescence spectroscopy; circular dichroism spectroscopy; Tau protein.

(C) 2021 by the authors. This article is an open-access article distributed under the terms and conditions of the Creative Commons Attribution (CC BY) license (https://creativecommons.org/licenses/by/4.0/).

\section{Introduction}

Nanotechnology is a new platform to produce novel nanomaterials for a broad range of biological and biomedical applications from sensing to drug delivery [1, 2]. Nanoparticles (NPs) are generally defined as any material having at least one dimension smaller than $100 \mathrm{~nm}$ 
and, due to its novel properties, have a diverse range of products with applications in diagnosis, drug delivery, food industry, paints, electronics, cosmetics, and sunscreens [3-5]. The use of nanotechnology and nanoparticles in biomedical treatments is known as nanomedicine [6,7]. One of the most important metal oxide nanoparticles is zinc oxide nanoparticles, which are widely used in consumer products due to their attractive chemical properties [8,9]. Commonly, $\mathrm{ZnO}-\mathrm{NPs}$ have been used for industrial purposes such as semiconductors in microelectronic devices and degradation accelerator of water pollutants by photocatalytic activity [10, 11]. Previous studies have shown that $\mathrm{ZnO}$ can be used in biomedical and cancer treatment, including ovarian, gastric, breast, and colon cancer [12, 13]. Despite their benefits, zinc oxide nanoparticles also have toxicities to some extent that cause toxicity through mechanisms such as releasing $\mathrm{Zn}_{2}{ }^{+}$cations and free radicals. Wan-Seob Cho et al. indicated that administration of $\mathrm{ZnO}$-NPs orally for 13 weeks causes long-term accumulation of nanoparticles in the organs such kidney, brain, liver, and spleen [14]. ZnO-NPs have antibacterial, antidiabetic, antioxidant, and protective effects, whereas other investigators recorded harmful impacts of $\mathrm{ZnO}-\mathrm{NPs}$ in the cultured human cells and experimental animals Further studies on these nanoparticles are necessary $[15,16]$. Zinc is known as one of the most abundant trace metals in the brain, which is not only involved in physiological processes in the brain, including signal transmission and nerve growth but also plays an important role in the pathogenesis of several neurodegenerative diseases such as Alzheimer's [17-19]. The zinc ion maintains the structure and function of a wide range of proteins, including proteins with enzymatic roles, cell receptors, and signaling [20]. It has been found that $\mathrm{ZnO}$-NPs interaction with proteins prompt structural alteration, and denaturation lead to adverse effects against biological systems [21, 22]. Tau-P belongs to the microtubule-associated proteins (MAPs) family, being recognized in 1975, by Weingarten et al., as a heat-stable protein and plays a pivotal role in stabilizing microtubules $[23,24]$. In healthy nerve cells, the Tau protein is located in the axon [25]. In patients with Alzheimer's disease, Tau-P loses its ability to bind microtubules. Therefore, its normal duty, which is keeping the well-organized cytoskeleton, is no longer effective [26]. Also, according to research, no study has been performed on the cell lethal effects of $\mathrm{ZnO}$-NPs on human neuroblastoma cell bristles and toxicity to the Tau protein. The purpose of this study is to achieve a variety of topics, including: Investigation of the lethal effects of zinc oxide nanoparticles on human neuroblastoma cell line with cell membrane disorders; better understanding of the interaction between zinc oxide nanoparticles and Tau protein; The possibility of nanoparticles binding to proteins and interfering with their function and stability.

The result of this study can provide valuable information for discovering a new compound with minimum side effects in the treatment of diseases such as cancer and understanding the nanoparticles and protein surfaces interaction, which contribute to many complex cellular processes.

\section{Materials and Methods}

Zinc nanoparticles were purchased from US Nano as a powder with a $20-50.5 \mathrm{~nm}$ particle size with a purity of $99 \%$ and a spherical morphology. Human Tau protein (SigmaUSA), Human neuroblastoma cell line (Pasteur Institute, Tehran, Iran), The metals composition Eagle's Minimum Essential Medium (Gibco), Fetal Bovine Serum (Gibco BRL), penicillin/streptomycin solution 100X, PBS tablet, MTT (3-(4, 5-dimethylthiazol-2-thiazol-2tl)-2, 5-diphenyl tetrazolium bromide) (Sigma), dimethyl sulfoxide (DMSO), Lactate dehydrogenase kit (Sigma). 


\subsection{UV-visible.}

The UV-visible spectra of Tau-P and Tau-Pin in the presence of varying concentrations of ZnNPs $(0,2,5,10,20,50 \mu \mathrm{M})$ were recorded in the wavelength range of $360 \mathrm{~nm}$ on Spectrophotometer.

\subsection{Fluorescence spectrophotometer measurement.}

Fluorescence measurements were registered on a Varian, Cary Eclipse fluorescence spectrophotometer. The excitation wavelength was set at $270 \mathrm{~nm}$, and emission was measured in the range of 300-400 $\mathrm{nm}$. The absorption and emission slot widths were adjusted to 5 and $10 \mathrm{~nm}$, respectively. Three sets of fluorescence measurements were recorded at temperatures of $298 \mathrm{~K}, 310 \mathrm{~K}$, and $315 \mathrm{~K}$ for different concentrations of ZnONPs $(0,5,20,50,100 \mu \mathrm{M})$.

\subsection{Circular dichroism $(C D)$ spectropolarimetry.}

The spectra were recorded using Jasco J-815 Circular Dichroism (CD) Spectropolarimeter. Measurements were performed in the UV region in the wavelength range 190-260 $\mathrm{nm}$ and recorded after at least $1 \mathrm{~min}$ of incubation required to interact with ZnO-NPs and tau protein.

\subsection{MTT assay.}

Cell toxicity was evaluated by MTT according to the standard method. In summary, human neuroblastoma cells $\left(5 \times 10^{3}\right.$ in $200 \mu$ culture medium, four replicates) are seeded in a 96-well culture plate. After that, we treat them with different concentrations of ZnO-NPs $(0,1$, $10,20,50,100 \mu g m L-1)$ concentration. At the end of the exposure time, a wash step was performed. Then, $20 \mu \mathrm{l}$ of MTT solution ( $5 \mathrm{mg} / \mathrm{L}$ ) was added to each well and incubated for 3 hours. Color formazan crystals produced from the reduction of MTT in $200 \mu$ of dimethyl sulfoxide (DMSO) were dissolved. Optical density (O.D.) solution at $540 \mathrm{~nm}$ wavelength was measured as an excitation wavelength using a spectrophotometer screen (Applied Biosystems, Life Technologies, Monza, Italy).

\subsection{Lactate dehydrogenase assay.}

The leakage of LDH in SH-SY5Y cells was determined with LDH assay (Sigma) according to the manufacturer. SH-SY5Y cells were plated into the 96-well plates and exposed to different concentrations of $\mathrm{ZnO}-\mathrm{NPs}(0,1,10,20,50,100 \mu \mathrm{gmL}-1)$. At the end of exposure, the aliquot of a $50 \mu 1$ cell medium was used for LDH activity analysis, and the absorption was measured using the ELISA reader at $490 \mathrm{~nm}$. It is also worth mentioning that all experiments were performed in triplicate.

\subsection{Statistical analysis.}

All experiments were performed in three days and triplicate. Statistical analysis of this study was performed using SPSS version 16, and the results were analyzed by one-way ANOVA. Data were shown as mean \pm standard deviations, and a significant level was considered compared to the mean of data $\mathrm{P}<0.05$. 


\section{Results and Discussion}

\subsection{UV-visible.}

The results of this experiment showed that at the beginning when Tau-P existed individually, the absorption rate was 360 nanometers at its minimum. By increasing the concentration of nanoparticles on zinc, the amount of adsorption gradually increases. Therefore, the structure of Tau-P is folded and accumulated due to interaction with zinc oxide nanoparticles. This procedure is quite similar to the occurrence of Alzheimer's disease [27] (Figure 1).

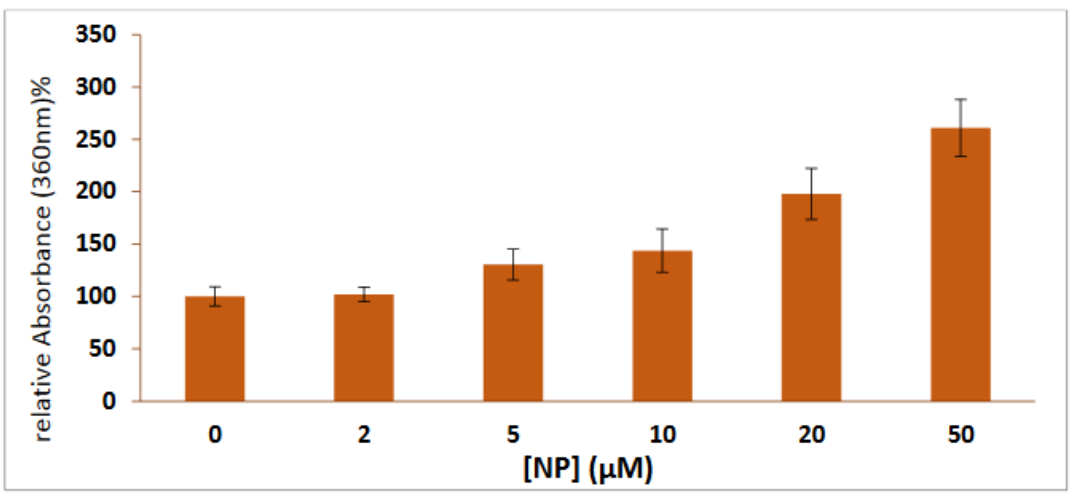

Figure 1. Uv-visible spectroscopy to measure the amount of light absorbed at $360 \mathrm{~nm}$.

\subsection{Fluorescence quenching studies of tau protein in the presence of $\mathrm{ZnO}-\mathrm{NPs}$.}

Fluorescence spectroscopy is used as a simple method to investigate changes in the structural interaction of biological macromolecules [28]. In fact, the fluorescence quenching mechanism can provide information about the displacement of fluorophores. Changes in the fluorescence spectrum of fluorophores often occur in response to changes in subunit conformation or bonding to the ligand [29,30]. Exposure of proteins to ligands such as nanoparticles can change the structure of proteins and finally change the function of proteins [31]. There are two types of fluorescence quenching mechanisms due to the interaction of the ligand with the protein, dynamic and static quenching [32]. The fluorescence static quenching is due to the formation of a less fluorescent complex in the ground state [33]. In comparison, dynamic quenching is due to a collision process among the protein and the ligand [34].

The fluorescence spectra of the Tau-P were recorded at temperatures of $298 \mathrm{~K}, 310 \mathrm{~K}$, and $315 \mathrm{~K}$. The outcomes showed the Tau-P protein has a strong emission band when excited with $270 \mathrm{~nm}$ wavelength, and as the concentration of ZnO-NPs increases, the intensity of fluorescence band gradually decreases. Therefore, zinc oxide nanoparticles lead to quenching of Tau-P as well as shifting the amino acid position of tyrosine fluorescence from the hydrophobic region to the hydrophilic region on the protein surface. This change in the fluorescence characteristic of the Tau-P indicates the binding between $\mathrm{ZnO}-\mathrm{NPs}$ and Tau-P to form a complex (Figure 2).

The fluorescence test confirmed the formed complex of nanoparticles and protein Tau$\mathrm{P}$, and a closer examination by the Stern-Volmer equation revealed that the type of mattress complex is static quenching (Figure 2). 
(A)

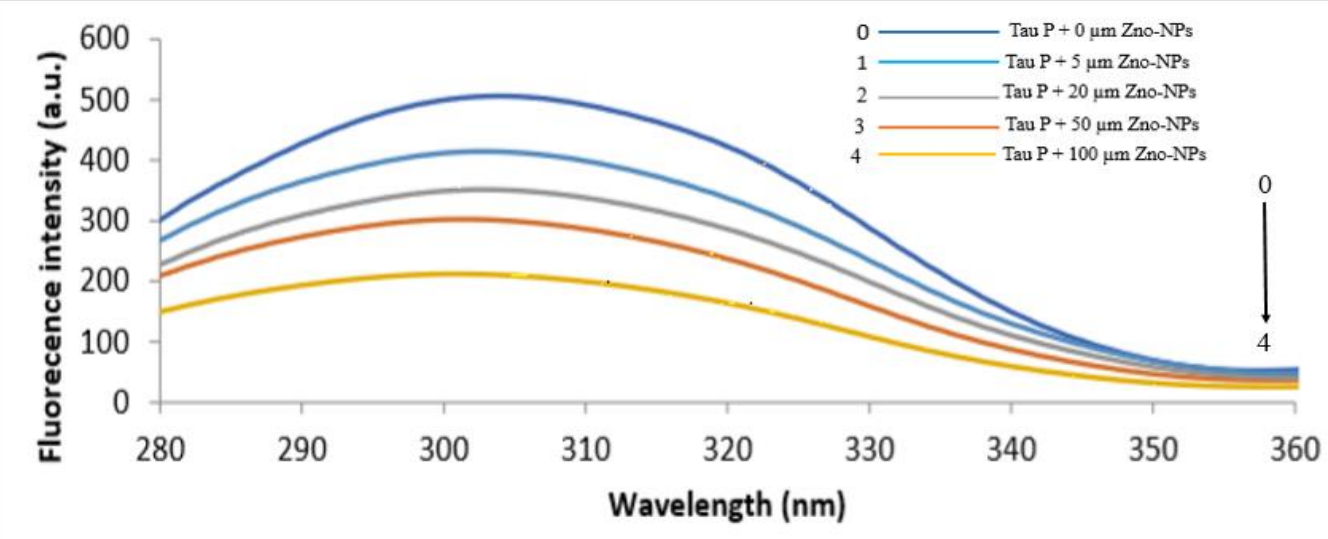

(B)

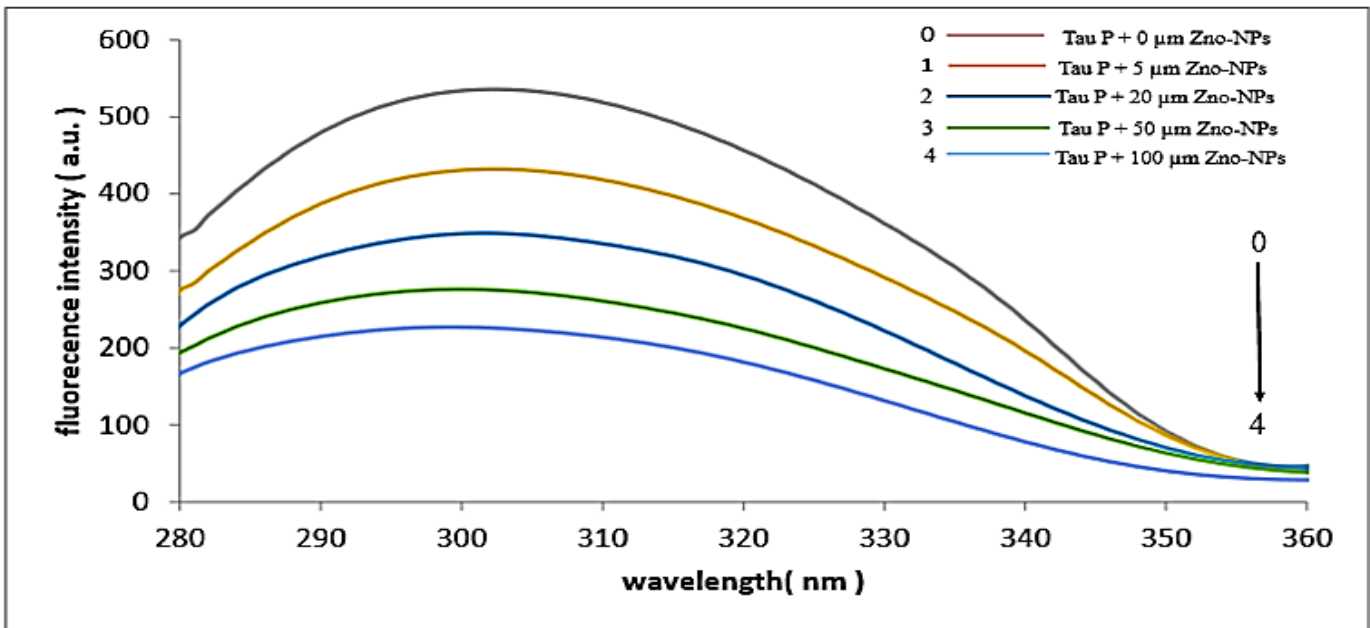

(C)

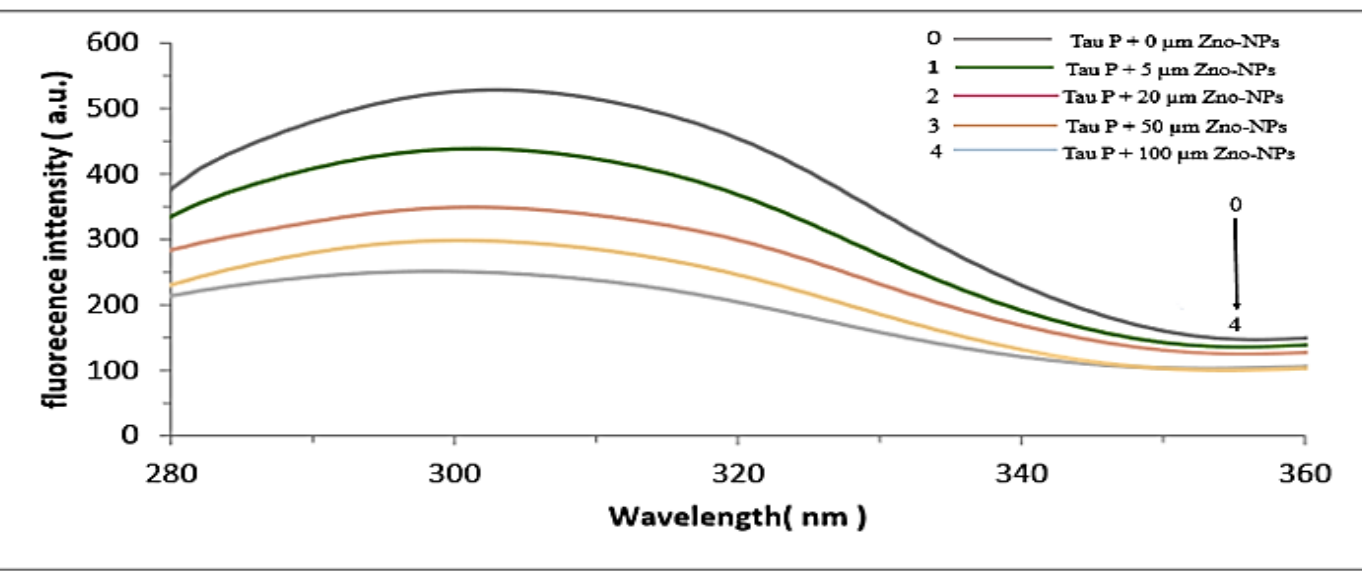

Figure 2. Fluorescence spectra, recorded for tau protein and ZnO-NP system, at the temperature of (A) 298, (B) 310, (C) $315 \mathrm{~K}$.

\subsection{Binding mechanisms between tau protein and $\mathrm{ZnO}-\mathrm{NPs}$.}

The fluorescence quenching data at different temperatures were analyzed by the SternVolmer Equation (Eq. 1)

$$
\text { (Eq. 1) } \frac{F O}{F}=1+k_{S V}[Q]
$$

The Stern-Volmer diagram of F0/F vs. [Q] is presented in Figure 5. The slope of the linear regression of this plot yields a Stern-Volmer constant (Table 1). As the temperature 
surges, the constant quenching drops. Thus, it can be concluded that the type of silencing mechanism is the interaction of zinc oxide nanoparticles with the Tau-P of static quenching. In fact, these nanoparticles are complex with Tau-P. (Figure 3)

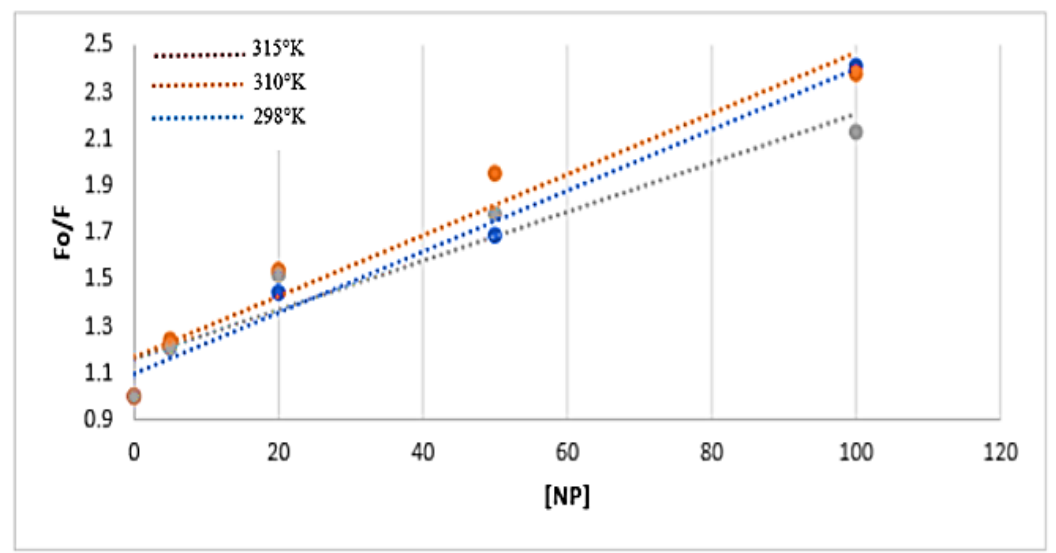

Figure 3. Stern-Volmer diagram of the interaction of tau protein with zinc oxide nanoparticles at temperatures $298,310,315 \mathrm{~K}$

Table 1. Stern-Volmer constant at 298, 310 and $315 \mathrm{~K}$.

\begin{tabular}{|c|c|c|}
\hline $\mathrm{T}(\mathrm{K})$ & $\mathrm{Ksv}\left(\mathrm{M}^{-1}\right)$ & $\mathrm{R}^{2}$ \\
\hline 298 & $1.35 \times 10^{8}$ & 0.98 \\
\hline 310 & $1.31 \times 10^{8}$ & 0.95 \\
\hline 315 & $1.05 \times 10^{8}$ & 0.93 \\
\hline
\end{tabular}

The Stern-Volmer linear diagram states that the Ksv protein complex decreases with increasing temperature (Figure 3). In line with our study, previous studies have reported that the binding constant of zinc oxide nanoparticles to albumin protein reduces with growing temperature (Table 1) [35,36].

\subsection{Number of binding sites and binding constant $\mathrm{ZnO}-\mathrm{NPs}$ and Tau-P complex.}

The fluorescence quenching data provides the information on the binding constant and the number of binding sites $(\mathrm{n})$ between the $\mathrm{ZnO}-\mathrm{NPs}$ and Tau-P; therefore, the data were analyzed at different temperatures by the Hill equation (Eq. 2) (Figure 4):

$$
\text { (Eq. 2) } \log \frac{F O-F}{F}=\log K+n \log [Q]
$$

As shown in Table 2, the binding remains constant, and the number of binding sites decreases with an increase in temperature. However, the decrease in Ksv is not so significant. This could mean that minor structural changes in the tau protein occur with increasing temperature. This, in turn, indicates that as the temperature rises, the binding of ZnO-NPs to the Tau-P becomes weaker. In other words, their bond is stronger at lower temperatures. It is also observed that the value of the $\mathrm{n}$ coefficient is approximately 0.5 , meaning that each number of $\mathrm{ZnO}-\mathrm{NPs}$ interacts with two Tau-P proteins. This result indicates the formation of an unstable complex of Tau-P with ZnO-NPs may decompose at higher temperatures. We examined the number of binding sites by the Hill equation and showed that each of $\mathrm{ZnO}-\mathrm{NPs}$ binds to 2 tau proteins (Figure 4-Table 2). 


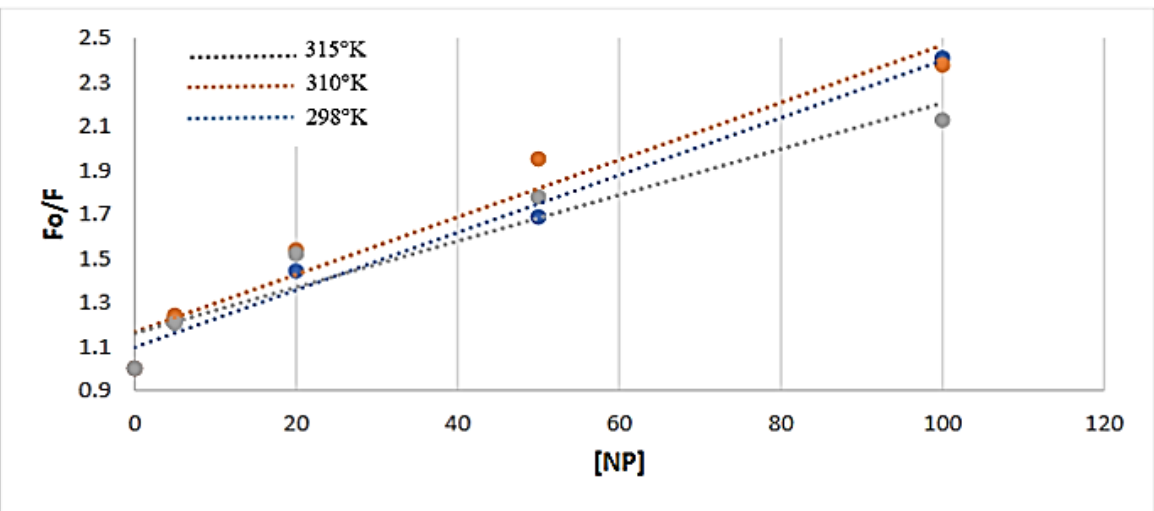

Figure 4. Hill plot of the interaction of tau protein with $\mathrm{ZnO}-\mathrm{NPs}$ at three different temperatures.

Table 2. Calculation of binding parameters of Tau protein interaction with $\mathrm{ZnO}-\mathrm{NPs}$ at three different temperatures.

\begin{tabular}{|c|c|c|c|c|}
\hline System & $\mathrm{T}(\mathrm{K})$ & $\log \mathrm{Kb}\left(\mathrm{M}^{-1}\right)$ & $\mathrm{n}$ & $\mathrm{R}^{2}$ \\
\hline \multirow{3}{*}{ ZnO-Tau } & 298 & 4.21 & 0.59 & 0.97 \\
\cline { 2 - 5 } & 310 & 4.20 & 0.58 & 0.99 \\
\cline { 2 - 5 } & 315 & 4.01 & 0.56 & 0.99 \\
\hline
\end{tabular}

3.5. Binding forces between $\mathrm{ZnO}$-NPs and Tau protein.

The thermodynamic parameters $\mathrm{DH}^{\circ}$ and $\mathrm{DS}{ }^{\circ}$ can be determined by Van't Hoff Eq (Eq. 3):

$$
\text { (Eq. 3) } \quad \ln K=-\frac{\Delta H^{\circ}}{R T}+\frac{\Delta S^{\circ}}{R}
$$

$\mathrm{K}$ is the binding constant at the corresponding temperature, and $\mathrm{R}$ is the gas constant.

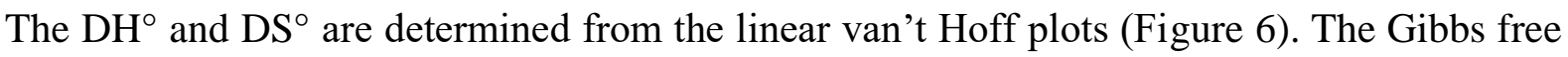
energy $\left(\mathrm{DG}^{\circ}\right)$ is estimated from the following Eq (Eq. 4):

$$
\text { (Eq. 4) } \Delta G^{\circ}=\Delta H^{\circ}-T \Delta S^{\circ}
$$
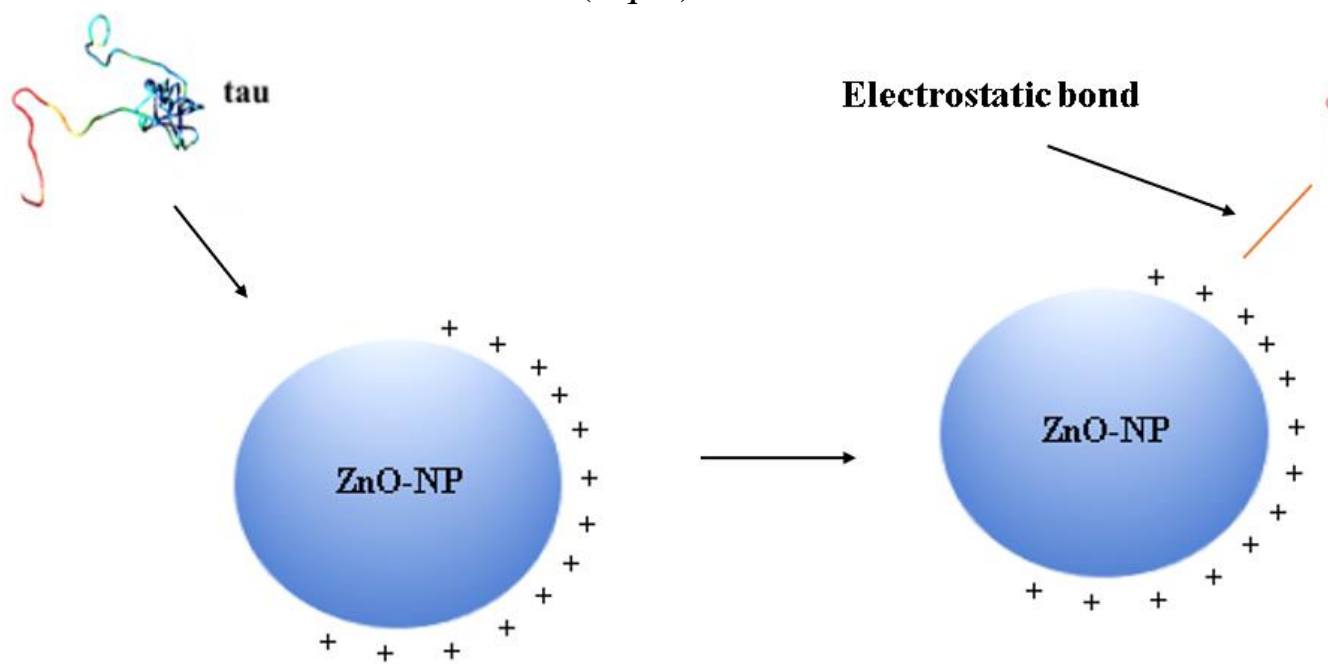

Figure 5. Schematic representation of the interaction between $\mathrm{ZnO}-\mathrm{NP}$ and tau protein.

The plot of ln vs. 1/T was fitted linearly to determine the value of $\mathrm{S}^{\circ}$ and $\mathrm{H}^{\circ}$ from the slope (Figure 6). Thermodynamic parameters are presented in Table 3. Bonding parameters were obtained for $\mathrm{ZnO}-\mathrm{NPs}$ and revealed that by increasing temperature (from $298 \mathrm{~K}$ to 315 
$\mathrm{K})$, the binding affinity of ZnO-NPs to Tau-P increased. The negative sign of Gibbs free energy changes indicates the binding process occurs spontaneously. The negative sign of $\Delta \mathrm{H}$ and the positive sign of $\Delta \mathrm{S}$ also indicate that the force involved in the bonding between the Tau-P and the $\mathrm{ZnO}-\mathrm{NPs}$ is electrostatic and ionic. In other words, positively charged zinc nanoparticles interact with negatively charged ligands on the tau protein (Figure 5).

Specific electrostatic interactions between ionic species in an aqueous solution are characterized by a positive $\Delta \mathrm{S}$ value and a negative $\Delta \mathrm{H}$ value. The negative sign for $\Delta \mathrm{G}$ manifested that the binding process was spontaneous $[38,37]$ (Figure 6- Table 3 ). To confirm our study, Bardhan et al. Showed that the force between zinc oxide nanoparticles and bovine albumin protein is electrostatic. The process of interaction of oxide nanoparticles on bovine albumin protein is spontaneous [39]. The study of the effect of zinc oxide nanoparticles on human albumin protein also confirms previous studies [40].

Another study in 2020 by Kumar et al. on albumin protein and zinc oxide nanoparticles showed negative enthalpy and entropy, which showed the formation of complexes with Van der Waals forces and hydrogen bonding. It indicates that thermodynamic forces play a pivotal role in the interactions of nanoparticles and proteins [41] Non-covalent weak forces play an undeniable role in the interactions of nanoparticles with biomolecules, which originate from hydrophobic, van der Waals, electrostatic, and hydrogen bonds [42]. Chakraborti et al. Found that the interactions of zinc oxide nanoparticles with Lactalbumin, one of the cow's milk proteins, after hemolysis with zinc oxide nanoparticles establish high-affinity van der Waals and hydrogen interactions [43].

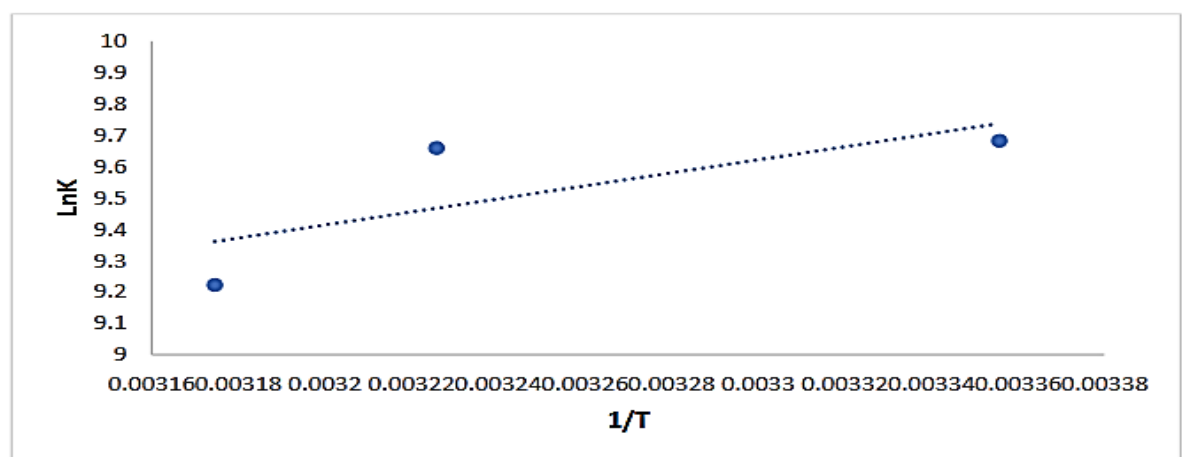

Figure 6. Van't Hoff Linear Diagram for the Interaction of Tau Protein with ZnO-NP.

Table 3. Calculation of Thermodynamic Parameters of Interaction of $\mathrm{ZnO}-\mathrm{NP}$ with Tau Protein.

\begin{tabular}{|c|c|c|c|c|}
\hline System & $\mathrm{T}(\mathrm{K})$ & $\Delta \mathrm{G}^{\circ}$ & $\Delta \mathrm{H}^{\circ}$ & $\Delta \mathrm{S}^{\circ}$ \\
\hline \multirow{3}{*}{ ZnO-Tau } & 298 & -24.07 & & 82.6 \\
\cline { 2 - 3 } & 310 & -24.34 & \multirow{2}{*}{-17.24} & 7.10 \\
\cline { 2 - 3 } \cline { 5 - 5 } & 315 & -24.46 & & 7.21 \\
\hline
\end{tabular}

\subsection{Circular dichroism spectroscopy.}

The CD spectrum of a protein in the $190-260 \mathrm{~nm}$ region provides information about its conformation with the secondary structure. As can be seen in Figure 7, the Tau-P has a peak at $195 \mathrm{~nm}$, indicating that it has a random coil structure. Increasing the concentration of oxide nanoparticles changed the structure of the Tau protein towards alpha-helix and beta-sheet. As the $\mathrm{ZnO}-\mathrm{NPs}$ concentration augmented from zero to $20 \mu \mathrm{M}$, the beta-sheet band increased from $10.4 \%$ to $12.7 \%$, and the alpha-helix band raised from $3.1 \%$ to $6.1 \%$. At the same time, the rate of random coil structure decreased from 62.3 to $59.1 \%$ and the turn structure from $24.2 \%$ to $22.1 \%$, which implies a reduction in the random coil structure in the Tao protein. The 
interaction of $\mathrm{ZnO}-\mathrm{NPs}$ with the Tau-P destroys the linear structure and random coil of protein and transformation into beta-sheet and alpha-helix structures. This change can lead to neurological disorders, according to Figure 7 and Table 4.

The results of dual CD spectroscopy showed that zinc oxide nanoparticles alter the structure of tau protein. Thus, the protein loses its function and accumulates. In addition, previous studies have shown that zinc oxide nanoparticles alter the structure of lysosomal and glucose oxidase proteins by decreasing the level of alpha-helix and increasing the structure of beta-sheet, causing their inactivation. [44, 45]. Previous studies demonstrated that the heart cystatin protein upon interaction with $\mathrm{ZnO}-\mathrm{NPs}$ led to the altered protein conformation [46] (Figure 7 and Table 4).

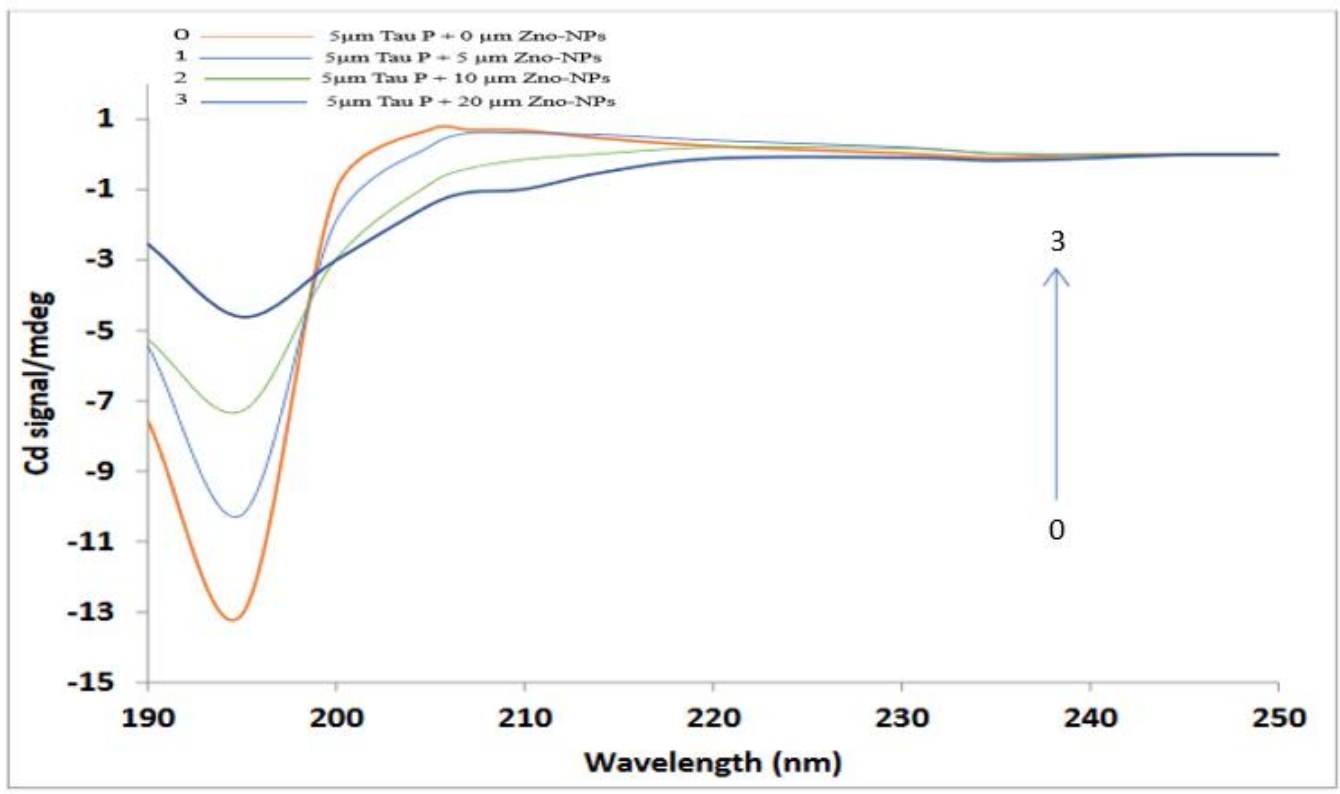

Figure 7. Circular dichroism spectra of Tau protein and $\mathrm{ZnO}-\mathrm{NPs}$ at different concentrations.

Table 4. Changes were observed in the secondary structure of the Tau protein by interaction with ZnO-NPs.

\begin{tabular}{|c|c|c|c|c|}
\hline$[\mathrm{NP}] \mu \mathrm{M}$ & Helix $\%$ & Sheet $\%$ & Turn \% & Random coil \% \\
\hline 0 & 3.1 & 10.4 & 24.2 & 62.3 \\
\hline 5 & 3.3 & 10.5 & 24.2 & 62.0 \\
\hline 10 & 5.4 & 11.4 & 23.1 & 60.1 \\
\hline 20 & 6.1 & 12.7 & 22.1 & 59.1 \\
\hline
\end{tabular}

\subsection{MTT assay.}

The results of the MTT test showed that exposing SH-SY5Y cells to ZnO-NPs for 24 hours resulted in reduced cell survival in a concentration-dependent manner. In the control group, $100 \%$ viability of the cells was observed, and before $10 \mu \mathrm{g} / \mathrm{ml}$ concentration of $\mathrm{ZnO}$ NPs, the decrease in cell viability was negligible. At a concentration of $20 \mu \mathrm{g}$, cell viability declined to $78.22 \%$ in comparison with the control group $(\mathrm{P}<0.05)$. By increasing the concentration of $\mathrm{ZnO}-\mathrm{NPs}$ to $100 \mu \mathrm{g} / \mathrm{ml}$, cell survival was reduced to $50.4 \%$ ( $\mathrm{p}<0.01$ ) (Figure 8). Evaluation of the MTT test on human neuroblastoma cells showed that the level of cellular activity was significantly reduced when exposed to 50 and $100 \mu \mathrm{M}$ zinc oxide nanoparticles. Although the results of this test were significant from 20 to $100 \mu \mathrm{M}$, the most notable changes were observed at concentrations of 50 and $100 \mu \mathrm{M}$. The results of our study are consistent with other studies on other categories of human cancer cells such as liver, kidney, and lung, which vary depending on the shape and concentration of nanoparticles (Figure 8) [47]. To confirm 
our study, Kim YJ et al. performed the antitumor effect of zinc oxide nanoparticles in the MCF7 cell line as a breast cancer cell model, and their results showed that the application of $31 \mu \mathrm{g}$ of this nanoparticle killed $50 \%$ of tumor cells [13].

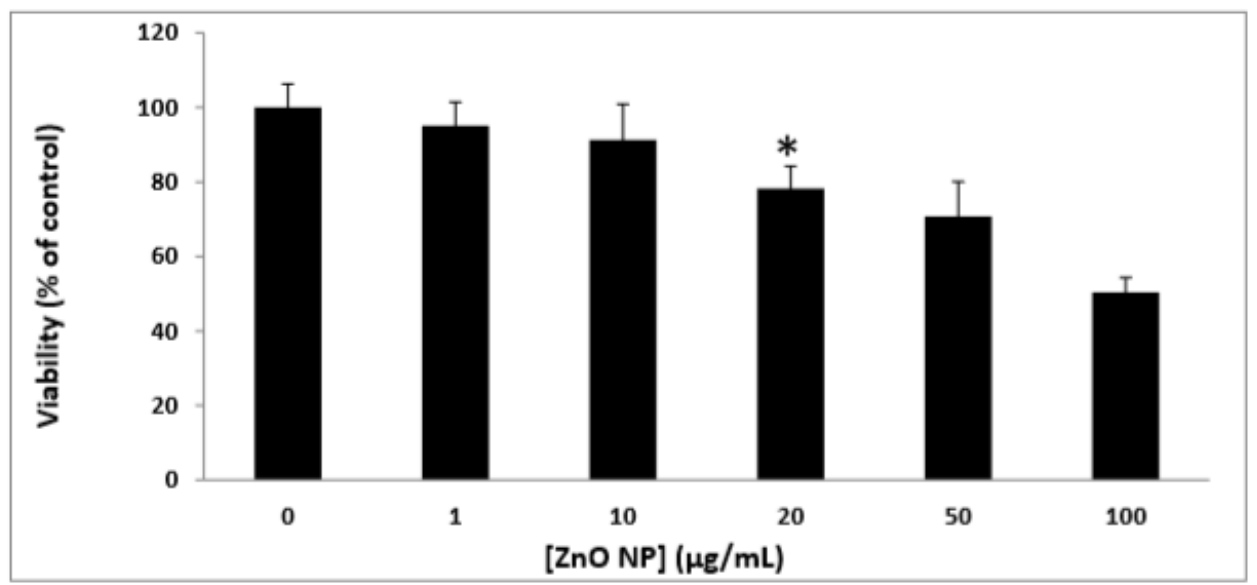

Figure 8. Evaluation of MTT assay. Different concentrations of ZnO-NP $\left(0,1,10,20,50,100 \mu \mathrm{gmL}^{-1}\right)$.

\subsection{Lactate dehydrogenase assay.}

In previous studies, cancer cells were found to have a very high expression of lactate dehydrogenase, which is associated with cancer progression [48]. During cell damage, the amount of lactate dehydrogenase released into the blood increases, which is used as a marker of tissue damage [49]. In the present study, ZnO-NPs caused cell damage and leakage of LDH from SH-SY5Y cells. Enzyme levels (LDH) in the group treated with 1 and $10 \mu \mathrm{g} / \mathrm{ml} \mathrm{ZnO-}$ NPs did not affect the control group significantly.

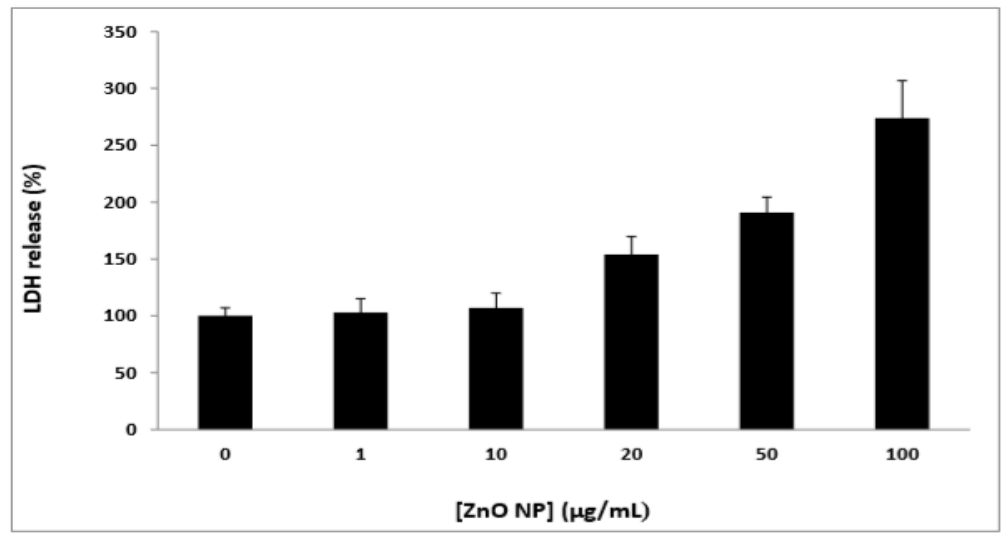

Figure 9. Evaluation of LDH assay. Different concentrations of $\mathrm{ZnO}-\mathrm{NP}\left(0,1,10,20,50,100 \mu \mathrm{gmL}^{-1}\right)$.

The level of LDH increased significantly at $20 \mu \mathrm{g}$ concentration and raised with concentration up to $100 \mu \mathrm{g}$ to 7.2-fold in comparison with the control group (Figure 9). A study conducted by Saud Alarifi et al. Indicated that by increasing the concentration of zinc oxide nanoparticles up to $20 \mu \mathrm{g}$ on human skin cancer cells for 48 hours, the amount of lactate dehydrogenase released significantly increased [50]. In 2020, a study showed that nanoparticles lead to cell hemolysis and membrane damage [51].

\section{Conclusions}

The results of our study indicated that zinc oxide nanoparticles reduce the viability of neuroblastoma cells and increase the leakage of lactate dehydrogenase from these cells. 
Besides, the results of the Stern-Volmer equation showed that the type of extinction mechanism of zinc oxide nanoparticles with Tau-P is static quenching. In fact, the results revealed that zinc oxide nanoparticles form spontaneously complex with Tau protein. Our observations of the interaction of zinc oxide nanoparticles with the Tau-P indicated the accumulation of the structure of this protein and indicated the change in the structure of the Tau-P from the random coil structure to the beta plate structure and alpha helix. Since the same factor leads to Alzheimer's disease, further study is essential in consuming these nanoparticles. The results also showed that the force between the complex of zinc oxide nanoparticles with Tau-P is electrostatic force. This force is more stable at the low temperature of this complex and the more the temperature increase, the more the bond of zinc oxide nanoparticles with Tau-P degrade.

\section{Funding}

This research received no external funding.

\section{Acknowledgments}

The authors are grateful to the Tehran University of Medical Sciences and Health Services for providing facilities.

\section{Conflicts of Interest}

The authors declare no conflict of interest.

\section{References}

1. Chauhan, S.; Jain, N.; Nagaich, U. Nanodiamonds with powerful ability for drug delivery and biomedical applications: Recent updates on in vivo study and patents. Journal of pharmaceutical analysis 2020, 10, 112, https://doi.org/10.1016/j.jpha.2019.09.003.

2. Mousavi, S.M.; Zarei, M.; Hashemi, S.A.; Ramakrishna, S.; Chiang, W-H.; Lai, C.W.; Gholami, A. Gold nanostars-diagnosis, bioimaging and biomedical applications. Drug metabolism reviews 2020, 52, 299-318, https://doi.org/10.1080/03602532.2020.1734021.

3. He, L.; Liu, Y.; Mustapha, A.; Lin, M. Antifungal activity of zinc oxide nanoparticles against Botrytis cinerea and Penicillium expansum. Microbiol Res 2011, 166, 207-215, https://doi.org/10.1016/j.micres.2010.03.003.

4. Vertegel, A.A.; Siegel, R.W.; Dordick, J.S. Silica nanoparticle size influences the structure and enzymatic activity of adsorbed lysozyme. Langmuir 2004, 20, 6800-6807, https://doi.org/10.1021/la0497200.

5. Al-Kordy, H.M.; Sabry, S.A.; Mabrouk, M.E. Statistical optimization of experimental parameters for extracellular synthesis of zinc oxide nanoparticles by a novel haloalaliphilic Alkalibacillus sp. W7. Scientific reports 2021, 11, 10924, https://doi.org/10.1038/s41598-021-90408-y.

6. Nel, A.; Xia, T.; Mädler, L.; Li, N. Toxic potential of materials at the nanolevel. Science 2006, 311, 622-627, https://doi.org/10.1126/science.1114397.

7. Ghouse, S.M.; Pugazhenthi, I. Nanomedicine: General Introduction from A to Z. Nanotechnology in Medicine, Springer 2021, 1-15, https://doi.org/10.1007/978-3-030-61021-0_1.

8. Mittag, A.; Hoera, C.; Kämpfe, A.; Westermann, M.; Kuckelkorn, J.; Schneider, T.; Glei, M. Cellular Uptake and Toxicological Effects of Differently Sized Zinc Oxide Nanoparticles in Intestinal Cells. Toxics 2021, 9 , 96, https://doi.org/10.3390/toxics9050096.

9. Pulit-Prociak, J.; Staroń, A.; Staroń, P.; Chmielowiec-Korzeniowska, A.; Drabik, A.; Tymczyna, L.; Banach, M. Preparation and of PVA-based compositions with embedded silver, copper and zinc oxide nanoparticles and assessment of their antibacterial properties. Journal of Nanobiotechnology 2020, 18, 148, https://doi.org/10.1186/s12951-020-00702-6. 
10. Ramesh, M.; Anbuvannan, M.; Viruthagiri, G. Green synthesis of ZnO nanoparticles using Solanum nigrum leaf extract and their antibacterial activity. Spectrochim Acta A Mol Biomol Spectrosc 2015, 136 Part B, 864870, https://doi.org/10.1016/j.saa.2014.09.105.

11. Alsaad, A.M.; Al Dairy, A.R.; Ahmad, A.; Al-anbar, A.S.; Al-Bataineh, Q.M. Synthesis and characterization of as-grown doped polymerized (PMMA-PVA)/ZnO NPs hybrid thin films. Polymer Bulletin 2021, 1-22, https://doi.org/10.1007/s00289-021-03600-5.

12. Tang, Q.; Xia, H.; Liang, W.; Huo, X.; Wei, X. Synthesis and characterization of zinc oxide nanoparticles from Morus nigra and its anticancer activity of AGS gastric cancer cells. J Photochem Photobiol B: Biology 2020, 202, 111698, https://doi.org/10.1016/j.jphotobiol.2019.111698.

13. Kim, Y.J.; Perumalsamy, H.; Castro-Aceituno, V.; Kim, D.; Markus, J.; Lee, S.; Kim, S.; Liu, Y.; Yang, D.C. Photoluminescent and self-assembled hyaluronic acid-zinc oxide-ginsenoside $\mathrm{Rh} 2$ nanoparticles and their potential caspase-9 apoptotic mechanism towards cancer cell lines. International journal of nanomedicine 2019, 14, 8195-8208, https://doi.org/10.2147/IJN.S221328.

14. Cho, W.S.; Kang, B.C.; Lee, J.K.; Jeong, J.; Che, J.H.; Seok, S.H. Comparative absorption, distribution, and excretion of titanium dioxide and zinc oxide nanoparticles after repeated oral administration. Part Fibre Toxicol 2013, 10, 9, https://doi.org/10.1186/1743-8977-10-9.

15. Padmavathy, N.; Vijayaraghavan, R. Enhanced bioactivity of $\mathrm{ZnO}$ nanoparticles-an antimicrobial study. Science and technology of advanced materials 2008, 9, 035004, https://doi.org/10.1088/14686996/9/3/035004.

16. Guan, R.; Kang, T.; Lu, F.; Zhang, Z.; Shen, H.; Liu, M. Cytotoxicity, oxidative stress, and genotoxicity in human hepatocyte and embryonic kidney cells exposed to $\mathrm{ZnO}$ nanoparticles. Nanoscale research letters 2012, 7, 602, https://doi.org/10.1186/1556-276X-7-602.

17. Morris, D.R.; Levenson, C.W. Neurotoxicity of zinc. Neurotoxicity of Metals 2017, Springer, Cham, 303312, https://doi.org/10.1007/978-3-319-60189-2_15.

18. Watt, N.T.; Whitehouse, I.J.; Hooper, N.M. The role of zinc in Alzheimer's disease. International Journal of Alzheimer's disease 2011, 2011, https://doi.org/10.4061/2011/971021.

19. DeBenedictis, C.A.; Raab, A.; Ducie, E.; Howley, S.; Feldmann, J.; Grabrucker, A.M. Concentrations of Essential Trace Metals in the Brain of Animal Species-A Comparative Study. Brain sciences 2020, 10, 460, https://doi.org/10.3390/brainsci10070460.

20. Huang, Y.; Wu, Z.; Cao, Y.; Lang, M.; Lu, B.; Zhou, B. Zinc binding directly regulates tau toxicity independent of tau hyperphosphorylation. Cell reports 2014, 8, 831-842. https://doi.org/10.1016/j.celrep.2014.06.047.

21. Chatterjee, T.; Chakraborti, S.; Joshi, P.; Singh, S.P.; Gupta, V.; Chakrabarti, P. The effect of zinc oxide nanoparticles on the structure of the periplasmic domain of the Vibrio cholerae ToxR protein. The FEBS journal 2010, 277, 4184-4194, https://doi.org/10.1111/j.1742-4658.2010.07807.x.

22. Kocyła, A.; Tran, J.B.; Krężel, A. Galvanization of protein-protein interactions in a dynamic zinc interactome. Trends in Biochemical Sciences 2020, 46, 64-79, https://doi.org/10.1016/j.tibs.2020.08.011.

23. Beharry, C.; Cohen, L.S.; Di, J.; Ibrahim, K.; Briffa-Mirabella, S.; Alonso Adel, C. Tau-induced neurodegeneration: mechanisms and targets. Neurosci Bull 2014, 30, 346-358. https://doi.org/10.1007/s12264-013-1414-z.

24. Yanagisawa, D.; Hamezah, H.S.; Arrozi, A.P.; Tooyama, I. Differential accumulation of tau pathology between reciprocal F1 hybrids of rTg4510 mice. Scientific reports 2021, 11, 9623, https://doi.org/10.1038/s41598-021-89142-2.

25. Wolfe, M.S. The role of tau in neurodegenerative diseases and its potential as a therapeutic target. Scientifica 2012, 2012, 796024, https://doi.org/10.6064/2012/796024.

26. Kontsekova, E.; Zilka, N.; Kovacech, B.; Skrabana, R.; Novak, M. Identification of structural determinants on tau protein essential for its pathological function: novel therapeutic target for tau immunotherapy in Alzheimer's disease. Alzheimer's research \& therapy 2014, 6, 45, https://doi.org/10.1186/alzrt277.

27. Simoes, S.; Neufeld, J.L.; Triana-Baltzer, G.; Moughadam, S.; Chen, E.I.; Kothiya, M.; Qureshi, Y.H.; Patel, V.; Honig, L.S.; Kolb, H.; Small, S.A. Tau and other proteins found in Alzheimer's disease spinal fluid are linked to retromer-mediated endosomal traffic in mice and humans. Science Translational Medicine 2020, 12, eaba6334, https://doi.org/10.1126/scitranslmed.aba6334.

28. Liu, R.; Wu, L.; Feng, H.; Tang, F.; Si, H.; Yao, X.; He, W. The study on the interactions of two 1, 2, 3triazoles with several biological macromolecules by multiple spectroscopic methodologies and molecular 
docking. Spectrochimica Acta Part A: Molecular and Biomolecular Spectroscopy 2020, 243, 118795 , https://doi.org/10.1016/j.saa.2020.118795.

29. Sedgwick, A.C.; Brewster, J.T.; Wu, T.; Feng, X.; Bull, S.D.; Qian, X.; Sessler, J.L.; James, T.D.; Anslyn, E.V.; Sun, X. Indicator displacement assays (IDAs): the past, present and future. Chemical Society Reviews 2021, 50, 90-38, https://doi.org/10.1039/C9CS00538B.

30. Wicks, S.L.; Hargrove, A.E. Fluorescent indicator displacement assays to identify and characterize small molecule interactions with RNA. Methods 2019, 167, 3-14, https://doi.org/10.1016/j.ymeth.2019.04.018.

31. Xu, J.; Zhang, M.; Cao, P.; Adhikari, B. Effect of ZnO nanoparticles combined radio frequency pasteurization on the protein structure and water state of chicken thigh meat. LWT 2020, 134, 110168, https://doi.org/10.1016/j.lwt.2020.110168.

32. Das, B.; Hossain, S.M.; Pakhira, B.; Pramanick, A.K.; Das, R.; Ray, M. Fluorescence quenching based detection of p-nitrophenol using luminescent silicon nanocrystals and insights into the quenching mechanism. Semiconductor Science and Technology 2020, 35, 035003, https://doi.org/10.1088/1361-6641/ab63f0.

33. Kardar, Z.S.; Shemirani, F.; Zadmard, R. Determination of iron (II) and iron (III) via static quenching of the fluorescence of tryptophan-protected copper nanoclusters. Microchimica Acta 2020, 187, 81, https://doi.org/10.1007/s00604-019-4067-4.

34. Deepa, H.; Thipperudrappa, J.; Kumar, H.M.S. Effect of temperature on fluorescence quenching and emission characteristics of laser dyes. J. Phys.: Conf. Ser. 2020, 1473, 012046, https://doi.org/10.1088/17426596/1473/1/012046.

35. Yang, H.; Liu, C.; Yang, D.; Zhang, H.; Xi, Z. Comparative study of cytotoxicity, oxidative stress and genotoxicity induced by four typical nanomaterials: the role of particle size, shape and composition. Journal of applied Toxicology 2009, 29, 69-78, https://doi.org/10.1002/jat.1385.

36. Qin, Y.; Zhang, Y.; Yan, S.; Ye, L. A comparison study on the interaction of hyperoside and bovine serum albumin with Tachiya model and Stern-Volmer equation. Spectrochimica Acta Part A: Molecular and Biomolecular Spectroscopy 2010, 75, 1506-1510, https://doi.org/10.1016/j.saa.2010.02.007.

37. Manjushree, M.; Revanasiddappa, H.D. A diversified spectrometric and molecular docking technique to biophysical study of interaction between bovine serum albumin and sodium salt of risedronic acid, a bisphosphonate for skeletal disorders. Bioinorganic chemistry and applications 2018, 2018, https://doi.org/10.1155/2018/6954951.

38. Suvarna, M.; Dyawanapelly, S.; Kansara, B.; Dandekar, P.; Jain, R. Understanding the Stability of Nanoparticle-Protein Interactions: Effect of Particle Size on Adsorption, Conformation and Thermodynamic Properties of Serum Albumin Proteins. ACS Applied Nano Mater 2018, 1, 5524-5535, https://doi.org/10.1021/acsanm.8b01019.

39. Bardhan, M.; Mandal, G.; Ganguly, T. Steady state, time resolved, and circular dichroism spectroscopic studies to reveal the nature of interactions of zinc oxide nanoparticles with transport protein bovine serum albumin and to monitor the possible protein conformational changes. Journal of Applied Physics 2009, 106, 034701, https://doi.org/10.1063/1.3190483.

40. Hassanian, M.; Aryapour, H.; Goudarzi, A.; Javan, M.B. Are Zinc oxide nanoparticles safe? A structural study on human serum albumin using in vitro and in silico methods. Journal of Biomolecular Structure and Dynamics 2021, 39, 330-335, https://doi.org/10.1080/07391102.2019.1711189.

41. Kumar, D.; Bhatkalkar, S.G.; Sachar, S.; Ali, A. Studies on the antiglycating potential of zinc oxide nanoparticle and its interaction with BSA. Journal of Biomolecular Structure and Dynamics 2020, https://doi.org/10.1080/07391102.2020.1803137.

42. Rashid, M.; Rabbi, S.N.I.; Sultana, T.; Sultan, M.Z.; Sultan, M.Z. Fluorescence spectroscopic study of interaction between olanzapine and bovine serum albumin. Pharm Anal Acta 2015, 6, 1000408, http://dx.doi.org/10.4172/2153-2435.1000408.

43. Chakraborti, S.; Sarwar, S.; Chakrabarti, P. The effect of the binding of $\mathrm{ZnO}$ nanoparticle on the structure and stability of $\alpha$-lactalbumin: a comparative study. J. Phys. Chem. B 2013, 117, 13397-13408, https://doi.org/10.1021/jp404411b.

44. Ren, X.; Chen, D.; Meng, X.; Tang, F.; Hou, X.; Han, D.; Zhang, L. Zinc oxide nanoparticles/glucose oxidase photoelectrochemical system for the fabrication of biosensor. Journal of colloid and interface science 2009 , 334, 183-187, https://doi.org/10.1016/j.jcis.2009.02.043.

45. Chakraborti, S.; Chatterjee, T.; Joshi, P.; Poddar, A.; Bhattacharyya, B.; Singh, S.P.; Gupta, V.; Chakrabarti, P. Structure and activity of lysozyme on binding to $\mathrm{ZnO}$ nanoparticles. Langmuir 2010, 26, 3506-3513, https://doi.org/10.1021/la903118c. 
46. Sohail, A.; Faraz, M.; Arif, H.; Bhat, S.A.; Siddiqui, A.A.; Bano, B. Deciphering the interaction of bovine heart cystatin with $\mathrm{ZnO}$ nanoparticles: Spectroscopic and thermodynamic approach. Int J Biol Macromol 2017, 95, 1056-1063, http://dx.doi.org/doi:10.1016/j.ijbiomac.2016.10.095.

47. Rahimi Kalateh Shah Mohammad, G.; Seyedi, S.M.R.; Karimi, E.; Homayouni-Tabrizi, M. The cytotoxic properties of zinc oxide nanoparticles on the rat liver and spleen, and its anticancer impacts on human liver cancer cell lines. J Biochem Mol Toxicol 2019, 33, e22324, https://doi.org/10.1002/jbt.22324.

48. Feng, Y.; Xiong, Y.; Qiao, T.; Li, X.; Jia, L.; Han, Y. Lactate dehydrogenase A: A key player in carcinogenesis and potential target in cancer therapy. Cancer medicine 2018, 7, 6124-6136, https://doi.org/10.1002/cam4.1820.

49. Miao, P.; Sheng, S.; Sun, X.; Liu, J.; Huang, G. Lactate dehydrogenase A in cancer: a promising target for diagnosis and therapy. IUBMB Life 2013, 65, 904-910, https://doi.org/10.1002/iub.1216.

50. Alarifi, S.; Ali, D.; Alkahtani, S.; Verma, A.; Ahamed, M.; Ahmed, M.; Alhadlaq, H.A. Induction of oxidative stress, DNA damage, and apoptosis in a malignant human skin melanoma cell line after exposure to zinc oxide nanoparticles. International journal of nanomedicine 2013, 8, 983-993, https://doi.org/10.2147/IJN.S42028.

51. Ziglari, T.; Anderson, D.S.; Holian, A. Determination of the relative contribution of the non-dissolved fraction of $\mathrm{ZnO} \mathrm{NP}$ on membrane permeability and cytotoxicity. Inhalation toxicology 2020, 32, 86-95, https://doi.org/10.1080/08958378.2020.1743394. 